\title{
環境中の N-ニトロソ化合物の分析法に関する研究（II）
}

一HPLCによるジアゾ化法を用いた環境中の亜硝酸の分析一

\author{
松居 正巳 \\ 株式会社島津製作所 応用技術部 \\ （３05 つくば市吾妻 $3-17-1$ ) \\ 石橋 亨・水野 竹美 \\ 財団法人日本医療食協会附属研究所 \\ （开203 東京都東久留米市前沢 $5-3-11)$ \\ 西川 雅高 \\ 国立環境研究所 \\ （テ305つくば市小野川16-2）
}

[平成 4 年 8 月 25 日受理]

\section{Study on Analysis of N-Nitroso Compounds in the Environment (II ) \\ - Determination of Nitrite in Environmental Samples by HPLC using Diazotization Reaction -}

\author{
Masami MATSUI \\ Tsukuba Analytical Applications Laboratory, Shimadzu Corporation \\ (3-17-1 Azuma, Tsukuba 305) \\ Tohru ISHIBASHI and Takemi MIZUNO \\ Japan Medical Foods Association, Research Laboratory \\ (5-3-11 Maezawa, Higashikurume, Tokyo 203) \\ Masataka NISHIKAWA \\ National Institute for Environmental Studies \\ (16-2 Onogawa, Tsukuba 305)
}

[Received August, 25, 1992]

\begin{abstract}
Summary
A new methods have been developped for the determination of nitrite in the environmental water samples by HPLC with post-column and the flow injection analysis (FIA) using diazotization reaction.

The optimum temperature and reaction time were investigated on the diazotization reaction of nitrite.

We could detect $0.001 \mathrm{ppm}$ of nitrite by HPLC and FIA using diazotization reaction and spectrophotometric detection where $540 \mathrm{~nm}$ of wave length was used. But it was observed in this method that some interferences existed.
\end{abstract}


Finally, we determined successfully nitrite in samples conteining high concentration of chloride such as tap and sea water by post-column HPLC using derivarization with diazonium salt.

Key words: Nitrite in water, Ion chromatograhy, HPLC, Post-column, Flow injection analysis.

\section{1.はじめに}

環境における亜硝酸は動植物や鉱物などに起因するも のと工業生産に伴って生成する人為的なものに分類され る。自然界では亜硝酸と硝酸の形態が可逆的な変化をす ることから同一のものとして考えられている。

亜硝酸は生体内や環境中において第 2 級および第 3 級 アミン類やアミド類などと化学的な条件で強い発がん物

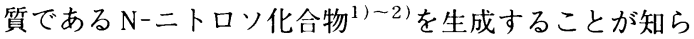
れている(3)-4)。また, この物質が湖沼, 河川, 内海な どの富栄養化の指標物質の一つであると考えられている ことから環境中の亜硝酸の存在を調べることは重要であ る。

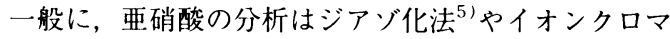
トグラフ法6)で行われている。ジアゾ化法は操作が簡単 であるが，反応時間を必要とするばかりではなく，フッ 素, 塩素, 硝酸, 硫酸イオンなどの成分との同時分析が できない。また、この反応を利用したフローインジェク ション分析法 (FIA) がある。亜硝酸以外にフッ素, 塩 素, 硝酸, 硫酸イオンなどの成分を同時に分析するイオ ンクロマトグラフ法は塩素イオンが多量に含まれ，亜硝 酸が微量な場合は分析できない。いずれにしても両者の 分析法は環境中の $0.1 \mathrm{ppm}$ 以下の微量な垔硝酸を分析す ることが困難である。

そこで，本研究は環境中の亜硝酸を正確に分析するた めに，ジアゾ化法を用いたポストカラムHPLC 法におけ るジアゾ化誘導体の反応時間や反応温度などについて検 討し, 環境中の亜硝酸分析法に適用した。さらに, 海水, 水道水, 雨水および湖沼水などの試料を用いて本方法と 従来のFIA やイオンクロマトグラフ法などで亜硝酸の 分析精度を比較し, 本法が環境中の亜硝酸分析において 従来の分析法よりも優れていたので報告する。

\section{2. 実験法}

\section{1 反応試薬の調製}

(1) スルファニルアミド溶液 スルファニルアミド $0.5 \mathrm{~g}$ と $12 \mathrm{~N}$ 塩酸 $5 \mathrm{ml}$ を $100 \mathrm{ml}$

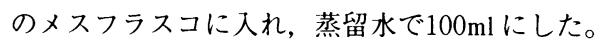

(2) ナフチルエチレンジアミン溶液 $\mathrm{N}-(1$-ナフチル) エチレンジアミン塩酸塩 $0.12 \mathrm{~g}$ を $100 \mathrm{ml}$ の蒸留水に溶解した。
(3) ジアゾ化反応試薬

スルファニルアミド溶液 $25 \mathrm{ml}$ とナフチルエチレン ジアミン溶液 $25 \mathrm{ml}$ を混合し, これを蒸留水で $200 \mathrm{ml} に$ なるように調整し, 亜硝酸のジアゾ化反応試薬とした。

\section{2 装 罟}

(1) HPLC 用ポンプ LC $-9 \mathrm{~A}$

(2) HPLC 用可視 - 紫外分光光度検出器 SPD-6AV

(3) HPLC 用電気伝導度検出器 CDD-6A

\section{3 分析条件}

(1) 装 置: HIC-9A System + Chromatopac C-R4A

(2) 力 ラ ム : Shim-pack IC-A1 (5mm I.D., 100mm L.)

(3) 移 動 相: $2.5 \mathrm{mM}$ Phthalic acid, $2.4 \mathrm{mM}$ Tris (hydroxymethyl) aminomethane

(4) 移動相流速: $1.0 \mathrm{ml} / \mathrm{min}$.

(5) カラム温度 : $40^{\circ} \mathrm{C}$

(6) 検 出 器: CDD-6A (Range 1) SPD-6AV (Abs. 0.01, 0.005)

(7) 反応液流速 : $0.1,0.5,1.0,1,5,2.0 \mathrm{ml} / \mathrm{min}$.

(8) 試料注入量: $20 \mu \ell, 200 \mu \ell$

\section{4. 試 料}

(1) 標準試料：フッ素, 塩素, 亜硝酸, 臭素, 硝酸, 硫 酸イオンの成分が各々 $20 ， 2.0 ， 0.2$, $0.02 \mathrm{ppm}$ になるように調整した。

(2) 分析試料: 水道水, 湖沼水, 雨水, 雪水, 海水

\section{3. 結果および考察}

\section{1 垔硝酸分析装置}

微量な亜硝酸の分析はジアゾ化反応を利用した方法で 行われている。この反応は有機化学の教科書によれば, Fig. 1 の化学反応式で説明される。

すなわち，亜硝酸イオンはスルファニルアミドによっ てジアゾニウム塩を, さらにN-(1-ナフチル) エチレン ジアミンがアゾ色素を生成する。この生成した化合物を 分光光度計の波長 $540 \mathrm{~nm}$ における吸光度から亜硝酸濃度 を求めている。

ここではFig. 1の反応をもとにFig. 2 のシステムの 装置を考案した。ここで严硝酸の濃度と吸光度において 定量的な関係が求めることができるならば, HPLCと FIA による亜硝酸の分析に適用できる。 

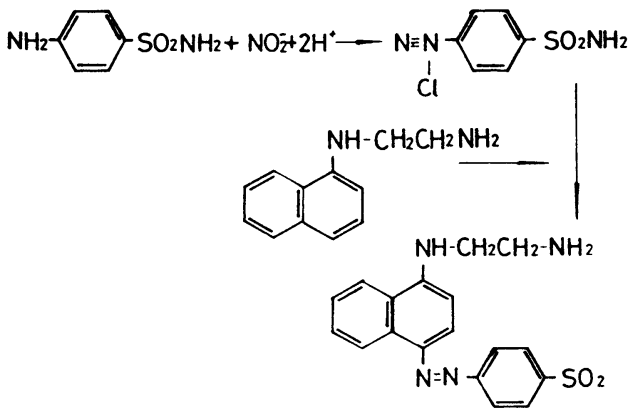

Fig. 1 Chemical formula of diazotization.

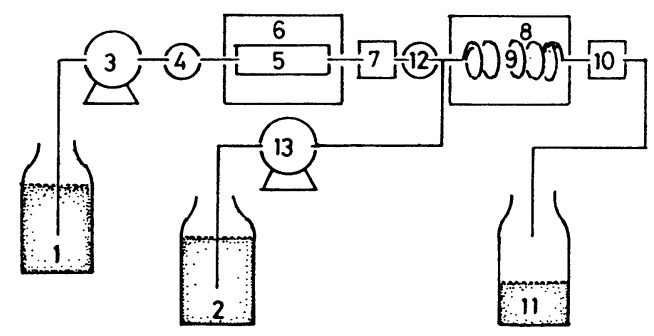

Fig. 2 Flow diagram of HPLC and FIA using diazotization reaction for nitrite analysis.

1. Mobile phase, 2. Reagent for diazotization, 3. Liuid pump, 4. Sample injector for HPLC, 5. Column, 6. Column oven, 7. Conductivity detector, 8. Reactor oven, 9. Reaction coil, 10. Spectrophotometric detector, 11. Drain, 12. Sample injector for FIA, 13. Reagent pump

Fig. 2 に示した装置の概略は次のように説明される。 すなわち,インジェクター（4）に導入された試料は, 容器内の移動相のキャリヤー液( 1 )によってポンプ( 3 ) を介してカラム槽（6) 内のカラム（5) に導かれ，そ こで亜硝酸と他の成分に分離される。分離された亜硝酸 は電気伝導度検出器 $(7)$ で検出される。

しかし, 電気伝導度検出器では微量な亜硝酸が選択的 に検出されないので, 電気伝導度検出器（7）の出口に ポンプ（13）を経た反応試薬（2）を，反応槽（８）内 の反応コイル（9）で亜硝酸と反応させ, 分光光度検出 器 (10) で検出する。

一方, FIA ではポンプ ( 3 ), インジェクター (4), カラム（5）を経た移動相（1）をキャリヤー液とし, 試料はインジェクター (12) から導入される。ポンプ(13) を経た反応試薬（2）を, 反応槽（8）内の反応コイル （9）で垔硝酸と反応させ, 分光光度検出器 (10) で検 出する。

\section{2 ジアゾ化反応試薬の流量と亜硝酸のピーク面皘}

ジアゾ化反応が亜硝酸イオンの定量分析に及ぼす反応 試薬の流速について検討した。

本実験では亜硝酸の濃度が0.1ppmの試料を用い, キャ リヤー液の流量を $1 \mathrm{ml} / \mathrm{min}$ とし, 反応試薬の流速が 0.1 , $0.5,1.0,1.5,2.0,2.5 \mathrm{ml} / \mathrm{min}$, 反応温度を $40^{\circ} \mathrm{C}$ に設 定し, 反応コイルの長が $2.0 \mathrm{~m}$ の条件で検討した。

その結果はFig. 3 に示したが, 垔硝酸濃度が $0.1 \mathrm{ppm}$ の試料でピーク面積は反応試薬の流量 $1.0 \mathrm{ml} / \mathrm{min}$ 以上が 亜硝酸の定量分析に適応できることがわかった。

\section{3 反応コイル長とジアゾ化反応の検討}

反応コイルの長さと亜硝酸の感度の関係を調べるため に内径が $0.1 \mathrm{~mm}$, 長さが $0.5,1.0,1.8,2.0,2.5$, $3.0 \mathrm{~m}$ のステンレス鋼管の反応コイルを用いた。

反応温度 $40^{\circ} \mathrm{C}$, 反応試薬およびキャリヤーの送液量を $1.0 \mathrm{ml} / \mathrm{min}$ に設定し，亜硝酸の濃度が $0.1 \mathrm{ppm}$ の試料を 用いた。Fig. 4 に亜硝酸濃度が $0.1 \mathrm{ppm}$ の試料における 反応コイルの長さと生成したアゾ化合物のピーク面積の 関係について示した。

反応コイルの長さは $2.0 \mathrm{~m}$ 以上であればジアゾ化反応 は一定となり，垔硝酸を定量的に分析できることがわ かった。

\section{4 ジアゾ化の反応温度と亜硝酸のピーク面積}

反応コイルの温度と亜硝酸のピーク面積の関係を求め るために，反応コイルの長さを $2.0 \mathrm{~m}$ ，温度を $20 \sim 99^{\circ} \mathrm{C}$ に設定し，悪硝酸濃度が $0.1 \mathrm{ppm}$ の試料を用いて検討し た。

Fig. 5 はその結果を示したが, 反応温度が高くなるに つれて亜硝酸のピーク面積が大きくなった。反応温度が

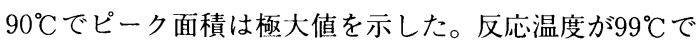
は減少し，その効率は $72^{\circ} \mathrm{C}$ とぼ同じであった。

これは反応温度が $90^{\circ} \mathrm{C}$ 以上になると, 反応試薬のスル ファニルアミドやN-(1-ナフチル) エチレンジアミン, あるいは亜硝酸との反応によって生成したアゾ化合物が 分解したと考えられた。

したがって，ジアゾ化反応を利用したポストカラム HPLC 法における亜硝酸の条件は反応カラムが $2.0 \mathrm{~m}$ 以 上, 反応試薬の流速が $1.0 \mathrm{ml} / \mathrm{min}$ 以上, 反応温度が $90^{\circ} \mathrm{C}$ などの条件が最適であった。しかし, 反応温度が $60^{\circ} \mathrm{C}$ 以 上になると反応槽から検出器出口に至る流路が加熱さ れ，気泡の発生が起こりやすい。このためにノイズの原 因となったので, 反応槽から検出器の流路を冷却するこ とで解決できた。本実験ではカラムを $40^{\circ} \mathrm{C}$ に設定して分 析しているので, 実験の簡便性を考慮し, カラム恒温槽 内に反応コイルを設置した。

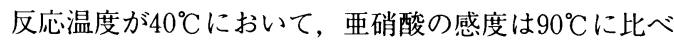




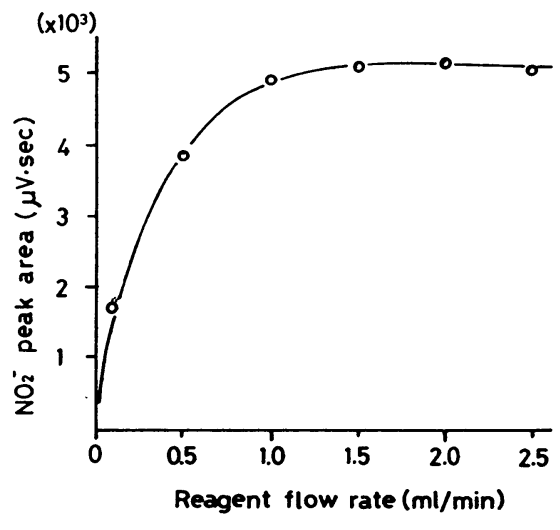

Fig. 3 Effect of nitrite peak area on reagent flow rate.

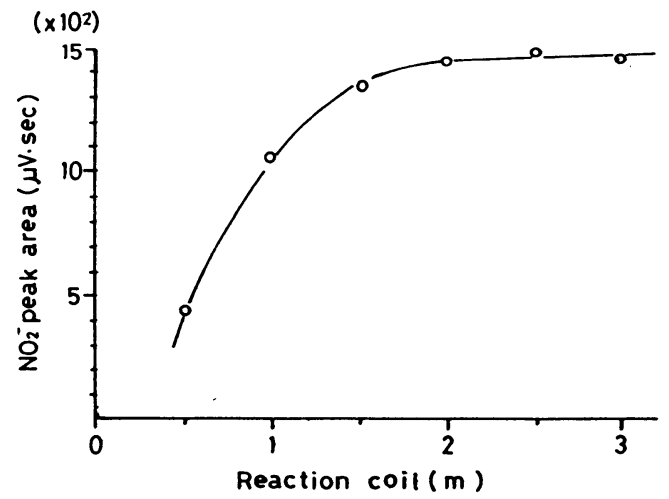

Fig. 4 Effect of nitrite peak area on length of reaction coil.

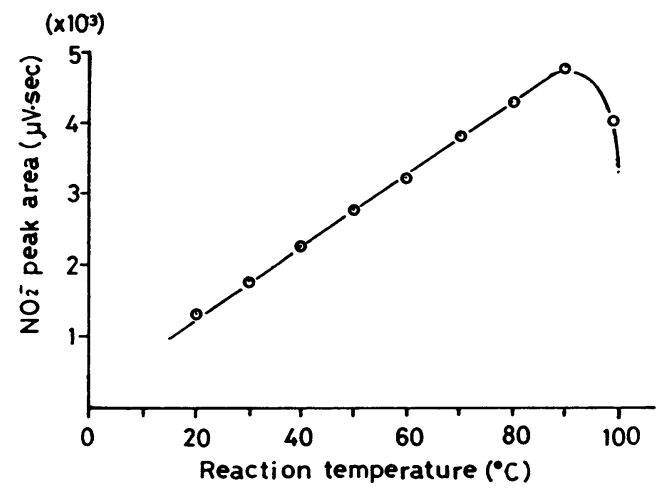

Fig. 5 Relationship of temperuture and peak area of nitrite.
て約 $1 / 2$ なるが, 濃度 $0.005 \mathrm{ppm}$ の亜硝酸試料を十分 に分析できたので, 今回の実験では反応温度を $40^{\circ} \mathrm{C} に$ 設 定して行った。

\section{5 垔硝䣷浱度とピーク面積の関係}

本法で垔硝酸を定量するために亜硝酸濃度とピーク面 積の関係について調べた。覀硝酸濃度が $0.005 〜 100 \mathrm{ppm}$ の範井の試料を測定し, そのピーク面積を求めた。

Fig. 6 は亜硝酸の濃度を横軸に, ピーク面積を縦軸に 対数グラフ上にプロットした。その結果, 覀硝酸の濃度 とピーク面積の関係において直線領域は $0.005 〜 10 \mathrm{ppm}$ であり，この領域が本方法おける亜硝酸の定量分析が可 能な濃度範囲であると判断した。

\section{6 HPLC およびFIAによる亜硝酸の分析精度}

本法における分析精度については亜硝酸の濃度が 0.005 1.00ppm の試料で行った。その精度の判定はそ れぞれの試料を10回測定し, 変動係数 (RSD 値) から 判断した。

Table 1 はその結果を示したが, 亜硝酸の濃度が 1 $\mathrm{ppm}$ では RSD 值が小さい。0.005ppmでも RSD 值は $5 \%$ 以下であった。なお，この分析条件では亜硝酸の検出限 界は0.0005ppmであった。

\section{7 環境試料における要硝酸分析法の比較}

本法とジアゾ化法を利用したFIA やイオンクロマト グラフ法で環境試料中の亜硝酸分析について比較した。

FIA 法ではFig. 7 に雨水と湖沼水の試料を分析した 測定例を示したが, 分析時間が短いことが特徵である。 試料 1 検体につき 1 分以内に分析が完了し, 同一試料を

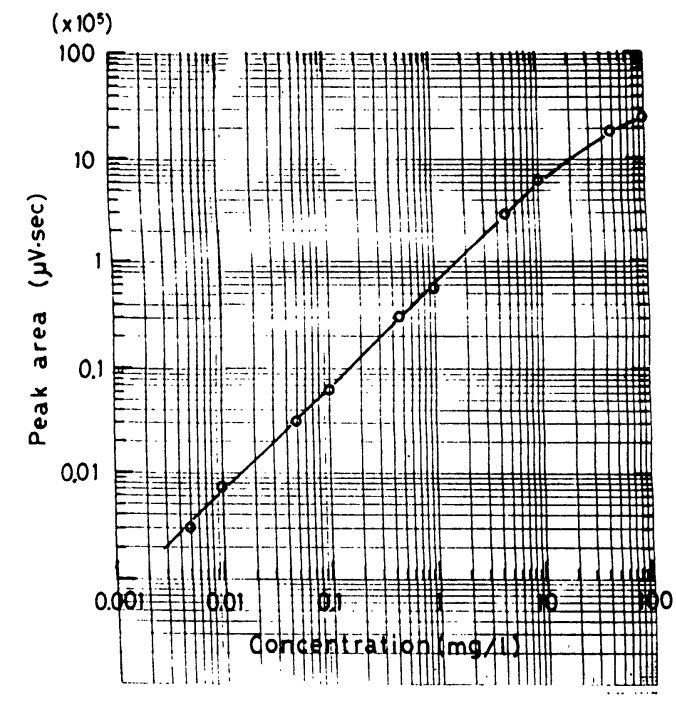

Fig. 6 Caliburation curve of nitrite. 
Table 1 Accuracy of nitrite on FIA and HPLC $(n=10)$

\begin{tabular}{|c|c|c|c|c|}
\hline \multirow{2}{*}{$\begin{array}{c}\text { Concentration } \\
\text { of nitrite }(p p m)\end{array}$} & \multicolumn{2}{|c|}{ F I A } & \multicolumn{2}{c|}{ H P L C } \\
\cline { 2 - 5 } & A.V. & RSD(\%) & A.V. & RSD(\%) \\
\hline 1.00 & 0.9961 & 0.837 & 0.9978 & 0.438 \\
\hline 0.10 & 0.0998 & 1.027 & 0.1014 & 0.781 \\
\hline 0.01 & 0.0105 & 2.791 & 0.0099 & 2.176 \\
\hline 0.005 & 0.0054 & 4.925 & 0.0049 & 3.904 \\
\hline
\end{tabular}

It used FIA and HPLC with spectrophotometric detector, nitrite detected as azo compound.

(I)

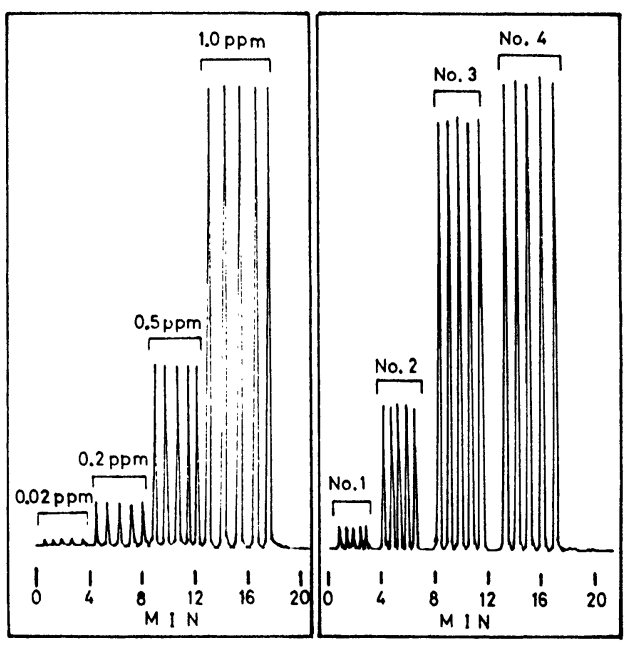

Fig. 7 FIA signal of standard and water samples.

( I ) ; Standard sample, ( II ) ; Water sample

No. 1 : Rain water (1), No.2 : Rain water (2)

No. 3 : Lake water (1), No.4 : Lake water (2)

5 回以上分析し, その平均値を求めたとしても5 分以内 には分析が完了できた。分析精度は別として，この方法 は迅速分析として有効な手段である。

一方, イオンクロマトグラフ法では塩素濃度が比較的 に高く, 亜硝酸濃度が低い試料中の亜硝酸分析に適用で きない。たとえば, 湖沼水中の亜硝酸分析に従来の電気 伝導度検出器を用いたイオンクロマトグラフ法で分析す ると Fig. 8 （I）のイオンクロマトグラムが得られる。
(I)

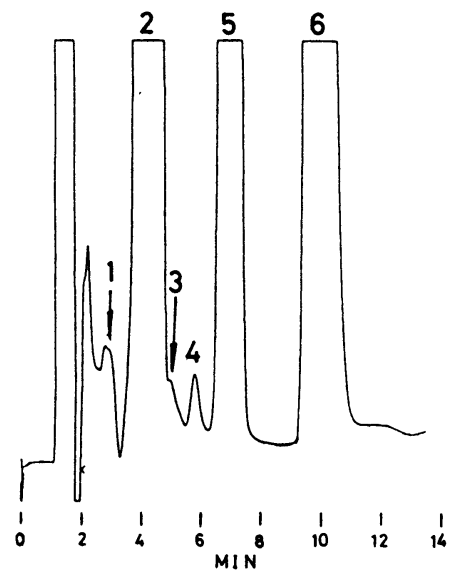

(II)

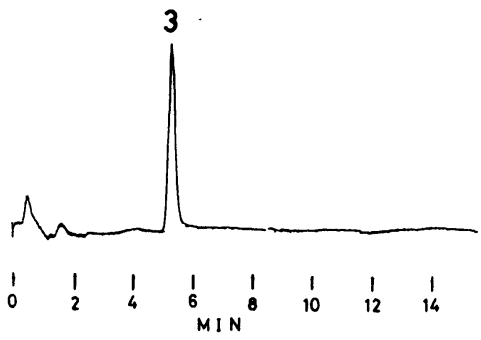

Fig. 8 Chromatograms of nitrite in lake water.

( I ) : Conductivity detector.

( II ) : Spectrophotometric detector $(540 \mathrm{~nm})$

$1 ; \mathrm{F}^{-}, 2 ; \mathrm{Cl}^{-}, 3 ; \mathrm{NO}_{2}^{-}, 4 ; \mathrm{Br}^{-}, 5$; $\mathrm{NO}_{3}{ }^{-}, 6 ; \mathrm{SO}_{4}{ }^{2-}$ 
塩素イオンピークのテーリング上に亜硝酸イオンが痕跡 程度に検出され, 実際には定量分析が困難である。

このような試料に対して, イオンクロマトグラフ法で は210～280nm の紫外部吸収を測定する間接吸光度型検 出法 ${ }^{7)}$ がある。本実験でこの方法を湖沼水試料の分析で 試みたが，亜硝酸イオンが検出できなかった。

他方, 本方法のジアゾカップリング反応を利用した HPLCの検出器は分光光度検出器を用い, 波長を $540 \mathrm{~nm}$ に設定して測定するとFig. 8 （II）のクロマトグラム が得られた。塩素イオンは検出されず, 亜硝酸イオンの ピークがはきりと検出され, 覀硝酸濃度 $0.0005 \mathrm{ppm}$ が 十分に検出できた。

特に，この方法は色素を含む試料では色素と亜硝酸が 分離するので天然物や食品試料などに適用でき, 亜硝酸 の分析に有効な手段であると考えられた。

\section{8 各分析法による垔硝酸の分析精度}

従来の電気伝導度検出器を用いたイオンクロマトグラ フ法とジアゾ化反応を用いたポストカラム HPLC および FIA 法による水道水, 湖沼水, 雨水, 雪水掞よび海水な どの試料中の亜硝酸の分析し, その定量結果についてそ れぞれの方法で比較した。

Table 2 はその結果であるが, 水道水, 湖沼水および 海水のように, 塩素が多量に含まれ, さらに亜硝酸濃度 が低い試料はイオンクロマトグラフ法で亜硝酸が分析で
きなかった。

また, ジアゾ化反応を用いたポストカラムHPLCと FIA 法を比較すると FIA 法はポストカラム HPLC 法に比 ベて亜硝酸が高い值を示している。

これはポストカラム HPLCにより海水中の亜硝酸を分 析したクロマトグラムFig. 9 で説明できる。すなわち, Fig. 9 （II）のクロマトグラム上では波長が540nm で亜 硝酸のピーク以外の成分が検出されている。ジアゾ化反 応を利用しFIA 法は, 亜硝酸以外の妨害成分も同時に 検出されるので, HPLCに比べて亜硝酸濃度が高い値を 示したと考えられる。FIA 法による亜硝酸分析に影響を 与えた成分は金属イオン, 陽イオン, 色素などが考えら れるが, 確認は行っていない。また, 海水や水道水よう に塩素を多量に含む試料は電気伝導度検出器を用いると Fig. 9（I）に示した如く, 塩素が妨害となり, 亜硝酸 が分析できない。

したがって, FIA 法では試料中に亜硝酸分析に対して 妨害成分が存在しないことを確認してから, 適用すべき である。また，イオンクロマトグラフ法による亜硝酸分 析では塩素イオンが多量に含まれ, 濃度が低い試料に適 用できない。

それに対し，ジアゾ化反応を用いたポストカラム HPLC は亜硝酸分析に妨害する成分の考慮する必要がな く, 亜硝酸が低濃度の試料に対しても正確な分析結果が 得られることがわかった。また,この方法は電気伝導度

Table 2 Comparison of nitrite contents in water samples by HPLC and FIA methods

\begin{tabular}{|c|c|c|c|}
\hline \multirow{2}{*}{ Water sample } & \multicolumn{3}{|c|}{ Nitrite content ( $p p m)$} \\
\hline & $\mathrm{FIA} *$ & $H P L C *$ & HPLC* \\
\hline Sea water $\begin{array}{l}(A) \\
(B) \\
(C)\end{array}$ & $\begin{array}{l}1.047 \\
1.151 \\
2.211\end{array}$ & $\begin{array}{l}\text { ND } \\
\text { ND } \\
\text { ND }\end{array}$ & $\begin{array}{l}0.156 \\
0.139 \\
0.166\end{array}$ \\
\hline Tap water $\left(\begin{array}{l}(A) \\
(B)\end{array}\right.$ & $\begin{array}{l}0.003 \\
0.003 \\
0.005\end{array}$ & $\begin{array}{l}\text { ND } \\
\text { ND } \\
\text { ND }\end{array}$ & $\begin{array}{l}0.002 \\
0.001 \\
0.002\end{array}$ \\
\hline $\begin{array}{r}(A) \\
\text { Lake water }(B) \\
(C)\end{array}$ & $\begin{array}{l}0.993 \\
1.020 \\
2.254\end{array}$ & $\begin{array}{l}0.674 \\
0.815 \\
0.502\end{array}$ & $\begin{array}{l}0.666 \\
0.771 \\
1.019\end{array}$ \\
\hline Rain water $\left(\begin{array}{l}(A) \\
(C)\end{array}\right.$ & $\begin{array}{l}0.111 \\
0.136 \\
0.417\end{array}$ & $\begin{array}{l}0.222 \\
0.102 \\
0.401\end{array}$ & $\begin{array}{l}0.231 \\
0.127 \\
0.411\end{array}$ \\
\hline
\end{tabular}

*) Spectrophotometric detector (Nitrite detected as azo compound)

**) Conductivity detector. (Ion chromatography) 
(I)

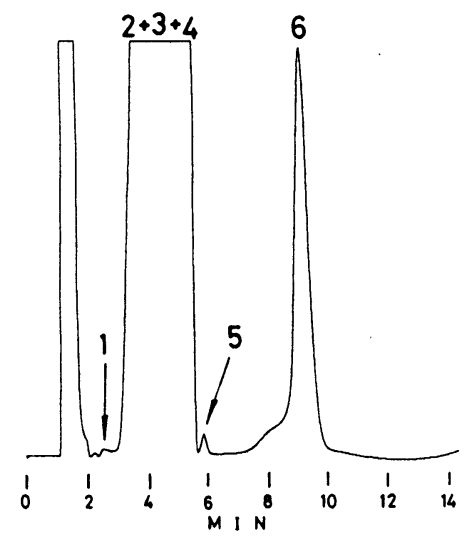

(II)

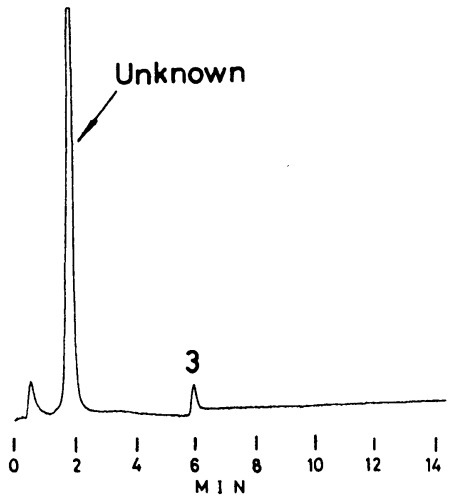

Fig. 9 Chromatograms of nitrite in sea water

( I ) : Conductivity detector.

( II ) : Spectrophotometric detector (540nm)

$1 ; \mathrm{F}^{-}, 2 ; \mathrm{Cl}^{-}, 3 ; \mathrm{NO}_{2}^{-}, 4 ; \mathrm{Br}^{-}, 5$; $\mathrm{NO}_{3}{ }^{-}, 6 ; \mathrm{SO}_{4}{ }^{2-}$

検出器と併用して使用できるので, 亜硝酸以外のフッ素, 塩素, 臭素, りん酸, 硝酸, 硫酸イオンなどの陰イオン 成分も同時に分析が可能であった。

\section{4. まとめ}

本法は環境試料中の亜硝酸イオンを選択的に，かつ高 感度で分析するためにジアゾ化法を用いたポストカラム HPLC の反応時間や反応温度などの分析条件について検 討し, 環境試料中の亜硝酸イオンの新しい分析法を見出 だした。

湖沼水, 河川水, 雨水, 海水, 水道水などを実験試料 として用い，本方法とFIA やイオンクロマトグラフ法 で覀硝酸分析の比較をした。FIA は亜硝酸イオン以外の 成分も検出し，本方法に比へ高い値を示した。また，イ オンクロマトグラフ法は塩素イオンが多量に含まれ, 亜 硝酸濃度が低い試料に適用できながった。

以上の結果から, 従来の環境水中の亜硝酸分析法には
試料によって分析が困難であったり，誤った分析値を示 し, 無意味な分析值を評価する結果となる。それに対し, 本方法は妨害成分と亜硝酸イオンをHPLCのカラムに よって分離した後, 反応コイルでジアゾ化法を用いたポ ストカラム法で選択的に高感度で検出しているので, 妨 害成分の影響も受けずに亜硝酸イオンが分析できた。本 方法が環境水中の亜硝酸を分析できる有効な手段である ことがわかった。

\section{要 約}

ジアゾ化反応を利用したポストカラム法について検討 し，HPLCとフローインジェクション分析法（FIA）を 併用した環境中の亜硝酸を分析法を開発した。

ジアゾ誘導体の反応よる亜硝酸の検出は分光光度検出 器の波長が $540 \mathrm{~nm}$ で反応時間，温度，試薬の流速の影響 などについて調べた。

FIA は水試料中の亜硝酸 $0.001 \mathrm{ppm}$ を検出することが できた。しかし、ジアゾ誘導体化を利用したFIAでは 亜硝酸以外に妨害成分があることがわかった。ジアゾ誘 導体化を利用したポストカラム HPLC 法では多量の塩素 イオンを含む水道水や海水などの試料中の亜硝酸を測定 することができた。

\section{文 献}

1) Druckrey, H., Preussmann, R., Ivankovic, S. and Schmahl, D.,: Organotrope carcinogene wirkungen bei 65 verschiedenen $\mathrm{N}$-nitroso-verbindungen an $\mathrm{BD}$ ratten, Z. Krebsforsch., 69, 103 201 (1967)

2) Magee, P.N. and Barnes, J.M.,: Carcinogenic N-nitroso compounds, Adv. Cancer Res. 10, 164 246 (1967)

3) Cuello, C., Correa, P., Haensezel, W., Gordillo, G., Brown, C., Archer, M. and Tannenbaum, S.,: Gastric cancer in Colombia. I. Cancer risk and suspect environmental agents., J. Natl Cancer Inst., 57, 1015 1020 (1976)

4) Epstein, S.S. Iobal, Z.M. and Johnson, M.D.: in vivo nitrosation of morphorine in mice by inhaled NOx. pp.195 204. "N-nitroso compounds: Analysis, formation and occurrence" Edited by Walker. E.A., Griciute, L., Castegnaro. M., and Borzsonyi, M. IARC Scientific Publications No.31, Lyon, International Agency for Research on Cancer, (1980)

5) 日本薬学会編：衛生試験法・注解, p.81 82, 1990, 金原出版株式会社（東京）

6）日本規格協会編：JIS ハンドブック 10 環境測定, p.131 140，1992，日本規格協会（東京）

7) 日本薬学会編：衛生試験法 - 注解, p.11 15, 1990, 金原出版株式会社（東京） 